Izvorni rad UDK 81'37:13(045)

doi: $10.21464 /$ fi38308

Primljeno: 21. 11. 2017.

\title{
Gordana Čupković
}

Sveučilište u Zadru, Odjel za kroatistiku i slavistiku, Ulica Mihovila Pavlinovića 1, HR-23000 Zadar gcupkov@unizd.hr

\section{Prikazi uma u Vetranovićevu Pelegrinu}

\begin{abstract}
Sažetak
S aspekta kognitivne semantike kategoriziraju se i interpretiraju doslovni i metaforični izrazi kojima se u Vetranovićevu Pelegrinu tematizira um, to izrazni konteksti pojmova: svijest, misli $i$ mravi. Razmatra se konceptualni sadržaj, otjelovljenost $i$ kulturna zadanost proučavanih primjera. Analizom konceptualnoga sadržaja i isticanjem univerzalne kognitivne utemeljenosti navedenih metaforičnih iskaza težište se s međuknjiževnih utjecaja pomiče na slike nesvjesnoga kao bitne regulatore značenja proizvedenih u djelu.
\end{abstract}

\section{Ključne riječi}

Mavro Vetranović, kognitivna semantika, konceptualna metafora, otjelovljenost, um, svijest, nesvjesno

\section{Uvod}

Malo je koje djelo hrvatske književnosti toliko intrigantno i toliko proučeno, a da u isti mah izmiče svim interpretacijama kao Vetranovićev Pelegrin. Spjev kojemu nedostaje završetak i naslov o putniku neidentificiranim svijetom, ${ }^{1} \mathrm{u}$ kojem se prepliću izokrenuta zbilja i fantastika, prešao je u svojoj recepciji put od pokuda zbog $»$ neumjerenosti $\ll^{2}$ i smjelih alegorijskih tumačenja ${ }^{3}$ do

Pavličić (2007) naznačuje da bi priređivački naslov Pelegrin valjalo preispitati s obzirom na to da se u djelu koristi samo oblik Piligrin. O tome raspravlja i Lupić. Naslov je u ediciji SPH preuzet iz naslova prijepisa iz 18 . st. Tekst djela priredio je Kaznačić, tiskanje sveska nadgledao je Jagić. Kako primjere ekscerptiram samo iz toga izdanja, zadržavam naslov Pelegrin, iako se ne bi moglo pouzdano tvrditi da je to oblik naslova koji je djelu dao autor. Štoviše, imajući na umu strukturnu i interpretativnu šarolikost djela, kanonizacija samo jednoga oblika naslova možda nije ni potrebna. Složenu tekstološku problematiku uspostave djela iznosi Lupić (2014), naznačujući da je moguće da Piligrin i nije nezavršen, nego da završetak djela nije pronađen. 2

Ovako piše Kaznačić u uvodnom osvrtu izdanja SPH: »Mislim da se on, poznavši svoju poetičnu sposobnost, odvaži, da većim, a ne samo prigodnijem djelom steče sebi neumrlo ime megju pjesnicima, te uze da napiše ' $P e$ legrina'. Ali još prije nego ga dovrši, njegov um obogaćen novijem naukama stade drugijem pogledom razmatrati svijet i uvigjati, da, ako razum ne obuzda fantaziju, ona jasno prijegje granice umjerenosti i zavede ljudsku misao na stranputice.« (Kaznačić 1872: II) Cilj ovog rada nije razmatranje književnih utjecaja pa se tako ne osvrćem na kompleks etiketiranja djela »krparijom « (o tome u novije vrijeme usp. Lupić 2014). O književnim toposima posredovanima u djelu usp. Grmača 2010. Prateći vertikalnu liniju alegorijskoga putovanja i dualističku rastrganost između tijela i duha, Grmača zaključuje da se »semantičko središte« djela tiče »putnikova traženja blaženstva« (Grmača 2010: 443). 3

Pavličić se kritički osvrnuo i na Medinijeva prilično smjela tumačenja djela u duhu tradicionalne alegorije (Pavličić 2007: 49), tumačenja koja otklanja i Fališevac (1988). 
afirmacije u suvremenosti, kao odraz graničnosti i manirizma, ali i kao zanimljiv izdanak uvijek aktualne fantastike. ${ }^{4}$

Vetranovićev putnik napušta uzlaznu liniju tipičnoga anagogijskog putovanja, čime se u znatnoj mjeri odmiče od tradicionalnoga dualizma, a time i od tradicionalnih alegorija i simbolizacija. Prelazeći granice stvarnosti i svjesnog, autor daje sliku svijeta bez središta u kojem se tradicionalne (srednjovjekovne) dihotomije i ustaljene slike, umjesto u organiziranoj hijerarhiji i na jasnoj razdjelnici, nalaze u kaotičnom preplitanju i trajno produciranim pretvorbama. ${ }^{5}$ U djelu se odvija kontinuirana dezintegracija tijela praćena disperziranošću i diskontinuitetom prostora i vremena: događaji se odvijaju, likovi se pojavljuju i nestaju bez objašnjavanja kauzalnosti. Potraga za odbjeglim mislima praćena potragom za niveliranjem tjelesnoga obličja, smjer (i vodiča) zadobiva samo povremeno i gotovo slučajno. ${ }^{6}$ Otjelovljenost ${ }^{7}$ i materijalnost pokazuju se bitnim uporišnim točkama proizvedenih značenja, što je vidljivo ne samo u predstavljanju konkretnih pojava nego i u konceptualizaciji apstraktnih entiteta kao što su misli i um.

Upravo se prikazivanje materijalizirana uma pokazuje jednom od tematskih okosnica djela, a što potvrđuje razmatranje konceptualnoga sadržaja pojmova: svijest, misli i mravi. Navedeni su pojmovi ili konvencionalno i denotativno povezani s domenom mišljenja (svijest i misli) ili se preslikavanjem specifičnih situacija i obrazaca uspostavljaju simbolične i konotacijske veze s pojmovima iz domene mišljenja (mravi). Pri tome se kao smjernica i kao osvrt nameće »rizomska« definicija:

»Mnogim ljudima u glavi raste stablo, ali sâm mozak je mnogo više trava nego stablo.« (Deleuze i Guattari 2013: 23)

U nastavku se Vetranovićevi prikazi uma smještaju u kontekst kognitivnosemantičkih pogleda te posebno u kontekst »rizomske« horizontalnosti, da bi se interpretacijom konceptualnoga sadržaja izdvojenih primjera ukazalo na potrebu razmatranja univerzalne utemeljenosti značenjskih osobitosti predočenih slika. Tim slikama odražava se materijalnost i otjelovljenost apstraktnih koncepata te kulturalni model povezanosti različitih bića i pretežno su utemeljene na predodžbenoj shemi spremnika i s njom povezanoj razdjelnici unutra-van.

\section{Kognitivizam i prikazi uma}

Omeđujući um otjelovljenošću i zadanošću iskustvom i kulturnim okvirima, određujući misao kao nesvjesnu, a apstraktne koncepte kao pretežno metaforične, kognitivisti - realistički i materijalistički - usmjeruju semantička proučavanja (usp. Lakoff 1987, Lakoff i Johnson 1980), a da se pri tome ne odriču konstruktivističkih shema te u određenoj mjeri i hijerarhizacije ljudskoga mišljenja. Kategorije su kao produkt nesvjesnog predstavljene bitnim odrazom interakcije uma, tijela i materijalnoga svijeta, a time su i iskustveno obilježene, čime se dovodi u pitanje strogo razdvajanje subjekta i objekta te tradicionalni dualizam (prvenstveno dihotomija tijela i uma), no ipak uz isticanje perceptivnoga dualizma lika i pozadine, što predstavlja i bitan segment konceptualizacije uzrokovanja (usp. Lakoff i Johnson 1999). Predodžbene sheme kao kognitivni uzorci, odnosno modeli koji organiziraju znanja pripadaju području nesvjesnoga, ljudi ih koriste ustaljeno, automatski i bez napora (usp. Lakoff i Turner 1989). Kognitivisti se upravo posredstvom razmatranja metaforičkih preslikavanja pokušavaju približiti razmatranju nesvjesnih mo- 
dela. Metaforička preslikavanja pokazuju znatnu podudarnost među jezicima i kulturama pa se određeni broj konceptualnih metafora uvriježeno shvaća i kao univerzalne specifičnosti ljudskoga mišljenja. Takve su specifičnosti i prostorna predodžbena shema spremnika (kao prostor unutra omeđen granicom), koja se određuje i s obzirom na tijelo i s obzirom na um, kao što se i osnovni orijentacijski odnosi (na primjer gore-dolje, ispred-iza) određuju s obzirom na položaj ljudskoga tijela. Predodžbena shema izvor-cilj-put obilježava pak kretanje i dinamičnost te je temeljena i na konceptualizaciji vremenskoga tijeka i uzrokovanja (događaja). Događaji se tipično konceptualiziraju kao akcije, stanja kao lokacije, a promjene kao kretanja (usp. Lakoff i Johnson 1999).

Gotovo istodobno s ranim kognitivističkim radovima, Deleuze i Guattari razmatraju prožetost semiotičkih, materijalnih i društvenih tokova problematizirajući važnost metafore i metonimije, premještajući ih iz primarne osobitosti jezika u segment učinaka. Razmatraju riječi-koncepte kao linije, kritički se osvrću na metafore stabla-korijena, uspostavljaju metaforu rizoma-kanala te kategorije posve zamjenjuju modelima (usp. Deleuze i Guattari 2013). Umjesto hijerarhijskoga sustava, njihova je slika uma karta prelijevanja. ${ }^{8}$ Razmatrajući odnos izraza i sadržaja, riječi i stvari, uspostavljaju sustav premreženih stratuma koji uspostavljaju »dvostruke artikulacije« koje pak tvore »segmentirane mnogostrukosti«. Odnos prema dualizmu obilježen je prividnim paradoksom; dualizam izraza i sadržaja jest stvaran, ali postoji »samo u glavi« (Deleuze i Guattari 2013: 75). Um je predstavljen kao organski stratum i kompleksno središte koje ima organizaciju »predljudske juhe« (Deleuze i Guattari 2013: 75) u koju su ljudi uronjeni djelovanjem, rukama (kao artikulacijom sadržaja) i licem (kao artikulacijom izraza).

Kognitivistički određujući i interpretirajući značenjske kategorije izdvojenih primjera dolazimo upravo do slike uma koja predstavlja kartu linija koje su

Pavličić detaljno razlaže fabulu djela te rastvara široku lepezu različitih čitanja, osobito naglašujući načela izokrenuta svijeta. Među ostalim, ističe da je priča Pelegrina »prikaz pustolovine ljudskoga duha« (2007: 69) te znakovito određuje i logiku sna kao mogući regulativ zbivanja $\mathrm{u}$ djelu: »život nije pravocrtni hod u proštenište, nije putovanje na kojem bismo imali zaštitnika i vodiča, nego je kaotičan san koji često nema ni zrnca smisla u sebi« (2007: 70); naznačujući pri tome i osobit Vetranovićev kriticizam mistične kauzalnosti: događaji nisu vođeni »božjom rukom《 pa je možda Bog »digao ruke od ovoga svijeta« (2007: 70). 5

Za proučavanje konceptualnog sadržaja izdvojenih segmenata djela, koje je i potraga za konceptualnom podlogom značenjskih učinaka, postaje irelevantno je li se kompleks značenja formirao intencionalnim crpljenjem književnih vrela ili su slike iz lektire pretopljene kolektivnim slikama $\mathrm{i}$ ishodišno činile nesvjesnu pozadinu autorske kreacije. Plod Vetranovićeve kreacije analogan je dehijerarhiziranom svijetu i acentriranom sustavu kakav opisuju Deleuze i Guattari (2013: 12, 25).
Rafolt navodi da je logika slučaja u pretvorbama Vetranovićevih likova slučajna jer nije osviještena (2009: 176), no ona je i značajan pokazatelj djelovanja nesvjesnoga.

7

U hrvatskoj kognitivnoj lingvistici uvriježen je naziv utjelovljenje za englesko embodiment. U ovom radu kao prijevodni ekvivalent navedene engleske riječi koristim termin otjelovljenje koji smatram prikladnijim, oblikom i zbog značenjske razlike: ulazak u tijelo - dobivanje, odnosno imanje osobina tijela. Potrebno bi bilo uspostaviti i razlikovanje prema religijskom konceptu utjelovljenja po Duhu Svetome, što je svakako tema koja nadilazi filološke kompetencije.

8

Kasniji kognitivisti približuju se toj slici stavljajući naglasak na pretapanje kao bitnu odrednicu mentalnih procesa (usp. Turner 1995) te u znatnoj mjeri usložnjujući sheme konceptualne integracije (usp. Fauconnier i Turner 1998). 
i koncepata koji su u stalnom bijegu i rasipanju te u opetovanom stvaranju i pretapanju, ${ }^{9}$ koju sliku je u 16. st. predočio autor koji je mnogo čitao i koji se otisnuo u tematizaciju misli u znatnoj mjeri obilježenu upravo materijalizmom. Vetranovićeva razmatranja otjelovljena uma, razmještanja misli i (a)kauzalnosti zbivanja u određenim su aspektima iznenađujuće bliska spomenutim filozofskim i kognitivističkim razmatranjima iz 20. st., što samo potvrđuje univerzalnost slika iznesenih u djelu.

Interpretativni ključevi Vetranovićeva spjeva mogu se naći u samom djelu. Kao što suhi javor kritički progovara o izokrenutu svijetu, ${ }^{10}$ tako mojemuča mala $^{11}$ izlažući o varljivu karakteru misli obrazlaže njihovu metaforiku. Taj odlomak donosim u nastavku: ${ }^{12}$

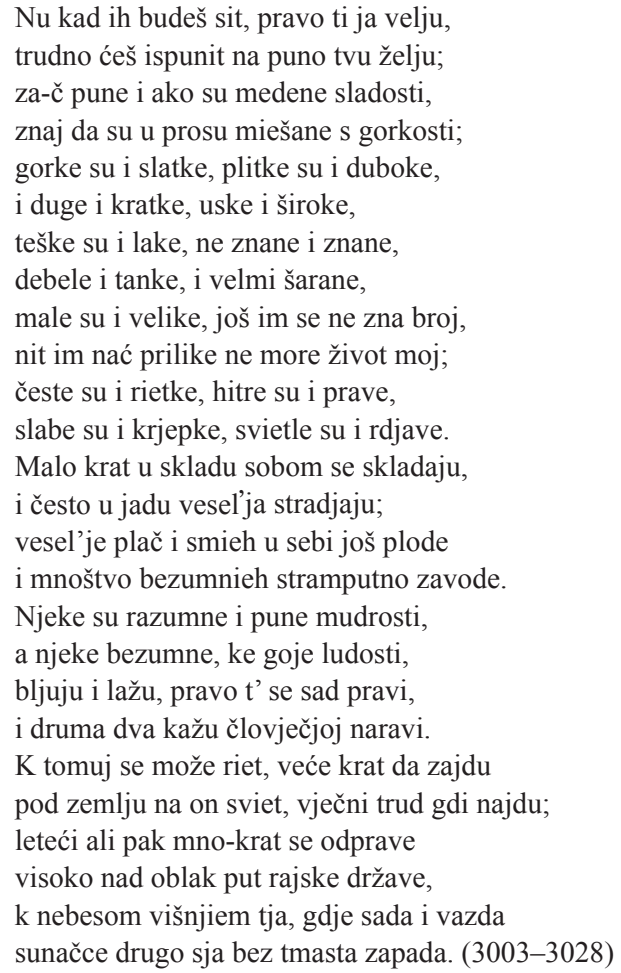

Iznesene poredbe mogu se razvrstati u sljedeće konceptualne metafore s pripadnim metaforičnim izrazima kojima se uglavnom posreduju jezične i književne konvencije: ${ }^{13}$

MISAO JE SPREMNIK: pune sladosti, plitke i duboke, pune mudrosti, iznjedruju | u sebi plode emocije (veselje, plač, smijeh)

MISAO JE TIJELO: duge, kratke, uske, široke, teške i lake, debele i tanke, male i velike, slabe i krjepke

MIŠLJENJE JE SPOZNAVANJE: ne znane i znane, razumne, bezumne

MISAO JE GOVORNI SUBJEKT: bljuju i lažu, goje ludosti, u skladu sobom se skladaju; druma dva kažu

MIŠLJENJE JE KRETANJE: hitre su i prave, stramputno zavode (uzrokovanje); zaj$d u$ pod zemlju i leteći visoko nad oblak, česte i rijetke (vrijeme)

Nabrojenim se metaforama za misli materijalizirano predočava apstraktni um pa su svodive na primarne konceptualne metafore: UM JE SPREMNIK i UM JE 
TIJELO $^{14}$ (potonja je metonimijski, DIO ZA CJELINU, projicirana u metaforama za dijelove uma: MISAO JE TIJELO, SVIJEST JE TIJELO). Tim se metaforama objedinjuju zapremanje prostora, kretanje i vremenski tijek, djelovanje i uzrokovanje (RAZUM JE SILA), kognicija i emocije. Naznačivanjem učestalosti kretanja misli (česte i rijetke) osim otjelovljenosti izražava se i linijski protok, povezivanje prostora $i$ vremena utemeljeno na konceptualnoj metafori VRIJEME JE PROSTORNO GIBANJE. Misli se sinestetski povezuju i s osjetilima: gorke i slatke (okus), svijetle i rđave (vid).

Razmatranjem konceptualnog sadržaja pojmova svijest, misli i mravi razmatra se odnos misli i svijesti (nesvjesnog i svjesnog), misli i tijela, misli i osobe, misli i kretanja, misli i djelovanja. Uspostavljanjem simboličnih poveznica i konceptualnih analogija misli i mrava razmatraju se poveznice tijela, apstraktnog djelovanja (mišljenja, osjetila, govorenja), kretanja i jedenja kao i shema rasutosti i neprestanog obnavljanja. Sve su navedene sheme pretopljene $u$ konceptualizaciji apstraktnoga uma te organizirane oko perceptivnog odnosa unutra-van kao središnje preokupacije subjekta.

\section{Primjeri}

Primjere za svijest, misli i mrave formalno razvrstavam u dvije skupine s obzirom na sintaktičko-semantička obilježja primarnog i sekundarnog objekta. ${ }^{15}$ Primjere iz skupine primarnoga objekta klasificiram s obzirom na konceptualna područja: objekt (nad kojim se vrše radnje) i agens (koji vrši konkretne i apstraktne radnje nad drugim objektima ili nad sobom), dok se primjeri se-

Rafolt ističe kako je »semantička i sintaktička disperzivnost (...) temeljno obilježje gotovo cjelokupnog Vetranovićeva stvaralaštva« (2009: 159).

10

Pavličić ističe kako javor progovara o društvenoj izopačenosti koja se preljeva i na dekadenciju prirodnih pojava (2007: 45). Topos »obrnutoga svijeta《i topos contemptus mundi, koje iščitava u govoru personificirana suhoga javora Grmača (2009) izdvaja i kao intertekstualnu poveznicu s Prologom Dugoga Nosa, Vetranovićeva "prijatelja« Držića, ističući kako oba odlomka »kroz alegoriju putovanja i uporabu istih toposa kritički propituju zbilju, nude isto motrište na svijet, i to ponajprije kroz etičke opozicije« (2009: 167).

11

Simboliku majmuna obilježavaju raspršena svijest i svijest u pogrdnom značenju: »... jer svijest osjetilnog svijeta prelazi s predmeta na predmet, kao što majmun skače s grane na granu.« (Chevalier i Gheerbrant 1994: 380) Majmun općenito označava nesvjesno koje se pokazuje u formi pogibeljnog, ali i kao nadahnuće i poticaj za djelovanjem: »Majmun, kao nesvjesno, posjeduje dvojak značaj, poguban poput vrača, probitačan poput vile, ali oba podjednako iracionalna.« (Chevalier i Gheerbrant 1994: 382) Curtius ističe kako je leksem simia »pomodna riječ latinske školske poezije « te učestala metafora u srednjovjekovlju (12. i 13. st.), kao i u novovjekovlju (15. i 16. st.), za osobe, apstraktne pojmove pa i tvorevine koje obmanjuju, slijedom toga i za učenike i oponašatelje (Curtius 1998: 602). Ona je u 16. st. i metafora umjetnosti (Gilio, 1564, scimia della natura, prema Curtius 1998: 603)

12

Navedeni odlomak citira i Fališevac (1988), kao potkrepu tvrdnji da je u spjevu prikazana slika obrnutoga svijeta, »ružnog, zlog i nesretnog, slika svijeta u kojem nema mira ni spokoja« (1988: 222).

13

Pojedini od navedenih metaforičnih izraza izrazito su konvencionalni i petrificirani, primjerice duboke misli. Metaforični izrazi kojima se naglašuje tjelesnost, primjerice krjepke misli i misli koje bljuju, za današnjeg čitatelja sadrže i element pjesničke inovativnosti. O odnosu konvencionalne i pjesničke metafore usp. Žic Fuchs 1992/1993. O suvremenim pristupima jezičnim i konceptualnim kriterijima određivanja konvencionalnosti i inovativnosti metafora usp. Stanojević 2013.

14

Sve konceptualne metafore navedene u ovom radu mogu se naći u knjizi Lakoff i Johnson 1999. 
kundarnoga objekta odnose na shemu spremnika; unutar izdvojenih konceptualnih područja izdvajaju se značenjske skupine kojima se može uspostaviti analogija među proučavanim primjerima.

\subsection{Svijest}

Primjeri za svijest čine najmanju skupinu primjera, njima se, s jedne strane, dovode u kontrast tijelo i duh, a s druge, naglašuje otjelovljenost duhovnoga, čime se taj kontrast briše.

(1') objekt

(1'a) posjedovanje

ter stojim sebe van, bez uma i sviesti, (3087)

(1'b) pomicanje objekta

Tiem leden i mrazan, ni u miru ni u goju, | zastranih sebe van daleče svies moju, (55-56)

ki pietjem zanieše mene van svies moju. (1032)

Još ako i plježu trbuhom po travi, | često svies uzdižu k nebeskoj državi. (2417-2418)

te rieči medene za-č neće prignuti | svies moju ni mene na taj jad priljuti; (3751-3752)

(1'c) djelovanje na objekt

i mravlje zlaćene svies moju skončaju; (3192)

(satir o magarcu, kao o zviri, koja se ne da jahati) ka s njeke naredbe svies moju svu skrati, (3265)

(blavor Pelegrinu) Zaman se tiem trudiš i trgaš svies tvoju, (2425)

$\mathrm{Nu}$ velmi svies moju me misli lomnjahu (...) (3677)

Posjedovanje uma i svijesti (1'a) pokazuje se ekvivalentom apstraktnoga sebstva; izvanjštenje svijesti iz tijela izjednačuje se s izvanjštenjem iz samoga sebe: stojim sebe van. ${ }^{16}$ To se izvanjštenje događa dok je trbuh pun misli koje se međusobno bore pa je ono, umjesto da određuje dualizam duha i tijela, ${ }^{17}$ odraz višestrukih pretapanja duhovnog i materijalnog. Analogija apstraktnoga sebstva i konkretnoga trbuha uspostavljena je posredstvom sheme spremnika kao i posredstvom apstraktnih entiteta (svijest i misli) koje taj spremnik ispunjavaju. Mnogostruke prepletenosti subjekta i sebe odražavaju i pokušaje uspostavljanja kontrole (koje se metaforizira kao posjedovanje objekta i kao bivanje, preciznije smještenost $u$ »normalnoj« lokaciji). ${ }^{18}$ Izvanjštenje iz sebe, koje je tipičan odraz metafore objektivnog gledišta, ${ }^{19}$ kod putnika dovodi do mnogih začudnosti uslijed materijalizacije nesvjesnoga. Izvanjštenje svijesti provodi subjekt kojemu svijest pripada (posesor), ali i drugi subjekti $\mathrm{u}$ interakciji s posesorom $\mathrm{i}$ to apstraktnim radnjama vezanim uz verbalne $\mathrm{i}$ druge auditivne senzacije (riječju i pjevanjem).

Izvanjštenje putnikove svijesti iz tijela i njeno smještanje $u$ otvoreni prostor »obratnoga« svijeta, kao suprotnost predodžbi uma kao spremnika, izraz je konceptualizacije uma kao tijela. Materijalizacija i eksternalizacija uma u tim se primjerima pokazuje dominantnim obilježjem u odnosu na konceptualizaciju njegove sakrivenosti naznačene nejasnom žudnjom (koja je i žeđ) te akauzalnošću.

Svijest kao objekt izvanjšten iz tijela može se pomicati ( 1 'b) dalje (udaljavati), gore i dolje. Opozicija trbuha i svijesti kao duha i tijela, ali i zemlje i neba (označeno prostornim odnosom gore-dolje) eksplicirana je u govoru štapa-blavora.

Preslikavanje iz domene materijalnoga predmeta osobito je vidljivo u primjerima djelovanja ( 1 'c) koje narušava integralnost, odnosno cjelinu objekta (smanjivanje, kao dokidanje opsega koje je i dokidanje, odnosno skraćivanje roka trajanja, odnosno vremenskoga tijeka: »skončavati« - »skratiti«). 


\section{(1") agens}

(1"a) kretanje i zapremanje prostora

moja svies po svietu da trudi svaki čas, | jak pčela po cvietu ištući mednu slas; (57-58)

i što sam obašla ja, trudna svies tvoja, (75)

u toj se u mene moja svies povrati, (69)

Ter zajde svies moja od zlata videći (1021)

kako će svies moja bez misli moć stati; (186)

(štap-blavor) zelen sam bio i suh, a sad je u meni | svies, pamet i živ duh, Piligrin ljuveni; (2413-2414)

(1'b) djelovanje

apstraktno

(ovčica-djevica) kojiem nać prilike ne može svies moja. (634)

toliko čudnu stvar po vrieme sve moje, | odkli sam na svieti i odkli me svies vlada, (1546-1547)

$\mathrm{Nu}$ ti će svies tvoja pravi drum kazati, | kako ćeš bez broja te misli vladati; (3161)

(zbog borbe misli) niednu stvar svies moja ne vie sad obrati, (3086)

Nemirna svies moja ner ni u čem na svieti | tihoga pokoja ne može vidjeti, (3079-3080)

jeda mi dobar glas naviesti svies moja: (68)

gdje meni svies reče: $(. .).(73)$

konkretno

da javi ni speći pritužna svies svoja | te mravlje gojeći ne prija pokoja. (3179-3180)

U navedenim primjerima vrši se preslikavanje iz domene tijela u pokretu te iz domene osobe koja vrši kognitivne radnje upravljanja, odabiranja, govorenja, spoznavanja (primjer za potonje utemeljen je na metafori ZNATI JE VIDJE-

15

S obzirom na fokus, objekt i akter, potonji je i agens (subjekt) tipično pripadaju planu lika ili primarnog objekta dok spremnik kao orijentir pripada planu pozadine ili sekundarnog objekta (o razlikama primarnog i sekundarnog objekta usp. Belaj i Tanacković Faletar 2014: 43-44). Kognitivisti uspostavljaju hijerarhijski poredak: subjekt kao lik prvoga plana, objekt kao lik drugoga plana, pozadina kao ostalo (usp. Belaj i Tanacković Faletar 2017: 155), no jasne razdjelnice unutar tako uspostavljene hijerarhije $u$ znatnoj se mjeri gube u slučaju razmatranja funkcija leksema, koji je istodobno subjekt, spremnik ili objekt užega odsječka teksta (sintagme i rečenice) $\mathrm{i}$ tema širega odlomka pa je fokalizacija misli i svijesti kao pozadine u tom slučaju diskutabilna.

16

Frazeološki izraz biti izvan sebe petrificirani je pokazatelj univerzalne konceptualizacije stanja kao lokacije te ujedno i Vetranovićeva tematska preokupacija u smislu raz(g)rađivanja sadržaja toga izraza. Tom se frazom povezuju emocije, prostor i tijelo čime je ona također iskaz otjelovljenosti uma. Učestalu emfatičnu uporabu navedene fraze u Vetranovićevu stvaralaštvu Kravar tumači pjesnikovom preokupacijom temom »odvajanja i eksterioriziranja pojedinih dijelova duše« (1980/1981: 319). Upravo je Kravar (1980/1981) u studiji koja je primarno usmjerena na osvjetljivanje književnih utjecaja popratno uputio i na pojedine motive koji predstavljaju podsvijest.

17

U glagoljskom prenju duše i misli, u kojem misao savjetuje (poučava) dušu (usp. Hrvatska srednjovjekovna proza II., 2013), misli su predstavnik svijesti i kontrast duši koja predstavlja tijelo, no ta je opozicija izrazito apstrahirana, tipično za sakralni kontekst uzdignuta na razinu simbolizacije, na kojoj tvarno postoji samo kao predmet govora, a ne i kao konkretan čimbenik u djelu.

18

Lakoff i Johnson na primjeru distinkcije subjekta i sebe ističu hijerarhijsku strukturiranost metaforizacije unutarnjeg života. Dvojstvo osobe, predstavljeno metaforom subjekt-sebstvo, postavljaju na najvišu razinu hijerarhije, a na nižim razinama izdvajaju pet specifičnih instanci te metafore utemeljenih na četiri tipa svakodnevnog iskustva: manipulacija objektima, smještenost u prostoru, ulaženje u socijalne odnose i empatička projekcija (Lakoff i Johnson 1999: 269).

19

»Ako želiš znati kako tvoja unutrašnjost izgleda izvana, trebaš izaći i pogledati.« (Lakoff i Johnson 1999: 277, prijevod G. Č.) 
тI) ${ }^{20}$ Sve su navedene radnje umanjene agentnosti. Svijest kao agens tipično djeluje na samu sebe (vrši radnje kretanja ili zapremanja prostora koji je i spremnik). U znatno manjem broju primjera svijest kao agens vrši konkretno djelovanje usmjereno na drugi objekt: uzgaja mrave, koje djelovanje metaforično označava sakrivene prostore uma; nesvjesno se, kako ćemo pokazati kasnije, otjelovljuje u mravima koje svijest čuva (uzgaja).

\subsection{Misli}

Razgranata metaforika misli posebno je utemeljena na preslikavanju iz domena materijalnoga predmeta i tijela.

(1') objekt

(1'a) posjedovanje

Što li ću nebog, rieh, kod vode studene | bez misli bez mojieh odlučit od mene? (871-872)

kako će svies moja bez misli moć stati; (186)

ne znavši sam što ću u pustoj dubravi | bez misli, u što ću skupit te mravi. (189-190)

Bez misli nebavac za toj sam ja zabio, | taj zlati peharac na kom sam mjestu skrio, (1669-1670)

(1'b) pomicanje

najliše gospoje čiem misli me zberu, (769)

gdje ć' misli sve skupit na volju u kril tvoj, (7898)

kad meni povrati misaoce sve moje, (931)

Za to sad, o móje, misli mi povrati, (2983)

Iz prosa čes moja zač da mi povrati | me misli bez broja, da moj trud prikrati: (195-196)

ter maglu razvija ter misli sve moje | po prahu rasija, u krovu da stoje. (109-110)

(u mieh) sve misli shranit mnieh, kako se podoba. (184)

u prosu da može me misli prinieti (192)

i misli sve tvoje k tomuj ćeš izgubit, (695)

(1'c) djelovanje

apstraktno

Nu ti će svies tvoja pravi drum kazati, | kako ćeš bez broja te misli vladati; (3161)

Te misli misleći, stiže me mrtvi san, | na travi ležeći jak da sam vina pjan, (3197-3198)

ter misli sve moje oćutih u meni, (3050)

konkretno

(našal) i misli sve moje u proso stvorene, (2293)

Mah misli u gori ne viem ki od boga | u proso satvori rad mene neboga, (111-112)

od velje tužice tve misli gojeći, (3034)

u proso stvorene, gdje nie živa duha, | mojemuča ner mala, ka ih sama bljude, (1660-1661)

me misli u prosu koje sam stradjal ja. (380)

ka s' misli sve moje u prosu pridala. (448)

Sam vazmi bisake ter misli sve tvoje | pozoblji iz šake, u prosu ke stoje. (3001-3002)

$\mathrm{Nu}$ kad ih budeš sit, pravo ti ja velju, (3003)

i misli probavi, kako znaš najbolje. (3038)

(1'd) smještenost

(proso mojemuča) do zrna pobrala, u kom su misli tve. (206)

... u kom su misli tve (464)

na ramu noseći pun misli šupalj mieh. (84)

Primjerima (1'a) iskazuje se nemogućnost posjedovanja (bez misli), a misli izvanjštene iz tijela antitetično zapremaju prazni spremnik: pun misli šupalj mjeh. Pomicanje se odnosi na rasutu skupinu: prosipanje, rasipanje, skupljanje i pohranjivanje te na donošenje i vraćanje cjeline. Misli kao objekt odraz su konceptualne metafore MIŠLJENJE JE OBJEKTNA MANIPULACIJA, što osobito do izražaja dolazi u konceptualizaciji misli kao cjeline. 
Primjeri apstraktnog djelovanja odnose se na radnje spoznavanja (upravljati, misliti) te osjećanja (ćutjeti), dok se konkretne radnje odnose na pronalazak, pretvorbu i čuvanje (misli u prosu) te na jedenje misli.

Posebno se izdvaja konceptualna metafora MIŠLJENJE JE JEDENJE, konkretizirana jedenjem misli pretvorenih u proso i osjećanjem misli u sebi (kao rezultat jedenja), što se slijedom toga prenosi i na apstraktni proces mišljenja pa se sitost izjednačuje s razboritošću: Sad se ću nazobat (prosa-misli), sad se ću nasitit, | sad se ću moći zvat i blažen i čestit; | sad ću moć misliti obilno za dosti, | kako ću ispliti iz trudne žalosti; (2891-2894). ${ }^{21}$

Misli su time izravno povezane s manifestacijama tjelesnosti (jedenje), ${ }^{22}$ kao odrazom žudnje za ovladavanjem materijom nesvjesnog. Povezivanje mišljenja s jedenjem tipično je utemeljeno na konceptualnim metaforama: UM KOJI DOBRO FUNKCIONIRA JE ZDRAVO TIJELO, IDEJE SU HRANA, STJECANJE IDEJA JE JEDENJE (usp. Lakoff i Johnson 1999: 241), no kod Vetranovićeva putnika suprotno očekivanju »zdravoga« tijela, sitost mislima izaziva tjelesne probleme jer su misli u stalnom nastojanju bijega, u težnji za izvanjštenjem, koja je po svome učinku dezintegracija tijela. ${ }^{23}$

(1") agens

(1'a) kretanje i zapremanje prostora

za-č misli sve bjehu u maglu zašle tja. (92)

misli su sve moje utekle od mene | i u gori tuj stoje u prosu stvorene! (181-182)

me misli pri tebi koje su ostale, | hoće li vrieme doć, da se u me povrate (2978-2979)

Za-č scienim u mene kad bi se vratile, | sve muke pakljene mnim bi mi skratile. (2981-2982)

sve se će u tvoj kril tve misli vratiti. (204)

misli će sve moje vrnut se u mene, | potajno ke stoje u prosu skrovene. (2889-2890)

me misli na moj plač, da se opet uhvate. (98)

njeke me k svietlomu istoku vodeći, | a njeke k biednomu zapadu goneći, (3075-3076)

ako se kad vratim gdje misli me stoje. (1668)

u prosu ke stoje i neće tvoje bit; (696)

beza dna od puča dublji je trbuh tvoj, | gdje misli te tvoje, koje su bez broja, |ne mogu da stoje u skladu bez boja; (3154-3156)

ke pri njoj tuj stoje, daleče od mene. (2294)

Nu moje misli sve niesu sad pri meni, | tiem sliedit dike tve dostojno nie meni; (607-608)

u pustoj dubravi gdje su misli moje, | od zlata gdje mravi pod javorom stoje, (775-776)

za-č misli sve moje daleč su ostale, | ostale od mene, kod javora suha, (1658-1659)

Pokli misli moje sa mnom čes rastavi, | u prosu ke stoje u pustoj dubravi, (873-874)

(1'b) djelovanje

apstraktno

da uprosim misli svieh, što mi će tuj reći; (90)

za-č misli nebogu mnoge mi govore: (3100)

20

Zahvaljujem anonimnom recenzentu koji me uputio na navedenu metaforu. 21

Piligrin je i stalno žedan. Upravo ga pijenje vode dovodi $\mathrm{u}$ »nevolje« s konkretnim tjelesnim razobličenjima, no ovdje se obratno od toga nada hranjenjem dostići određenu razinu apstraktnoga uma.

22

Jedenje u sakralnom kontekstu srednjovjekovne literature pripada metaforici učenja i žudnje za znanjem (usp. Curtius 1998: 150152).

23

Ustaljeni izrazi tih metafora u svakodnevnom govoru su: »žeđ za znanjem«, »(nije to lako) probaviti«, "zagristi (za nešto)«, "prežvakavati stare stvari«, »ostaviti loš okus u ustima« itd. 
Misaoce a druge mnoge mi govore: (3111)

ter ti će misli riet obilno za dosti, | kamo ćes ti zaniet tvoj život i kosti. (429-430)

misaoce za-č moje meni će svjeta dat, (2895)

A misli šarene šaren mi svjet daju, (3191)

jeda me napute na koji drum pravi (2985)

(trbuh se nadu kao mijeh) a misli u meni staše se karati. (3056) (i htješe puknuti na poli trbuh moj) misli se karaju u meni nebogu, | i trud mi zadaju, ki podniet ne mogu; (3145)

Ne bi toj za dosti, u karu što bjehu, | s nemirne žalosti ner se još kuniehu, (3071-3072)

konkretno

ner svaka način svoj hotješe obrati, (3069)

koje mi tolik trud zadaše nebogu, (3051)

i da mi tmastu noć u bil dan obrate? (2980)

ar misli tolik boj u meni provode, | ter trudan život moj stramputno zavode. (3083-3084) gdje ništo život moj obrati ne znaše, | od misli razlik broj gdje me tač rvaše. (3139-3140) i u tojzi nezgodi misal me rvaše, | što satir pješ hodi a na oslu ne jaše? (3237-3238)

$\mathrm{Nu}$ velmi svies moju me misli lomnjahu, (3677)

velmi se za prami zlosrdo vlačeći, | i objema šakami po bocieh mlateći (...) (3073-3074)

Konceptualizacija otjelovljenih i personificiranih misli (koje imaju svoju volju neovisnu o subjektu) kretanjem se odnosi na njihov bijeg od subjekta kojemu pripadaju (posesora) te na očekivanje povratka, na njihovo upravljanje subjektovim kretanjem te na njihovu odvojenost od posesora, koja je ujedno i smještenost u prostoru, u drugom obličju ili kod drugih likova, ili koja je smještenost u trbuhu posjedovatelja. Metaforični izraz odlaska misli u maglu utemeljen je na konceptualnoj metafori ZNATI JE VIDJETI.

Apstraktno djelovanje tipično se odnosi na govor i može se opisati općom konceptualnom metaforom MIŠLJENJE JE JEZIČNA AKTIVNOST (pri čemu je jezična aktivnost govorenje i(li) pisanje, usp. Lakoff i Johnson 1999: 244). Tom se metaforom podrazumijeva konceptualizacija eksternalizacije misli i njezine strukturiranosti po načelu linearnih sekvenci (usp. Lakoff i Johnson 1999: 245). Misli se obraćaju putniku, ali se personificirane misli smještene $u$ trbuhu (umjesto $u$ glavi) međusobno i svađaju i psuju. ${ }^{24} \mathrm{U}$ konceptualizaciji misli kao agensa (govorenja) naglašuje se i njihova pripadnost subjektu: posesivom (moje), dativom smjera i osobe (mi) te odmilicom (misaoce), koji su sve pokušaji ovladavanja mislima (i uspostave kontrole): misli savjetuju subjekt i on želi biti sit misli.

Metafora MIŠLJENJE JE RASKRIŽJE odražava se usmjeravanjem na put, ali i zadavanjem konkretnih tjelesnih problema. Misli konkretno djeluju na integritet tijela kao i na integritet uma u kojima su smještene (provode boj, rvu i lome), pri čemu se u jednom primjeru izravno suprotstavljaju svijesti (»lome svijest moju«). Uz to personificirane misli djeluju i na vlastita tijela (tučnjava misli međusobno). ${ }^{25}$

Konceptualne metafore MIŠLJENJE JE JEDENJE i MIŠLJENJE JE GOVORENJE pokazuju se i kao temelj dijalektičke opreke stvari i propozicija, ${ }^{26}$ koju Deleuze (2015) povezuje s dvojstvom uzroka i učinka, netjelesnih stvari i tjelesnih događaja ističući kako nad radikalnom dvojnošću dominira artikulacija razlike tijela i jezika (2015: 28). Ta se artikulacija razlike (unutarnjeg) tjelesnog i (vanjskog) predstavljenog navedenim konceptualnim metaforama pokazuje univerzalnom i ljudskom umu imanentnom.

(2) spremnik

Tiem vazmi proso toj i zoblji kako znaš, | u misleh život tvoj na volju da vladaš. (425-426)

U misleh ja takoj sebe van stojeći, (65)

Mnieh, da mi bridak mač gorčije od jada, | u misleh stojeć tač, trudan duh propada, (3129-3130) 
Bivanje u spremniku misli, koje je i održavanje (samo)kontrole, također se predstavlja kao rezultat jedenja (prosa-misli). Bivanje u mislima (kao spremniku) označuje i nerazboritost (dok je svijest na putu, subjekt je u mislima, ali izvan sebe). To je posebno podcrtano time što mu je duh napadnut (kao mačem) upravo dok je u mislima. Konceptualizacijom misli kao spremnika osim konvencionalnoga izraza smještenosti biti u mislima izražava se i opozicija subjekt-sebstvo (iskazana i u skupini primjera za svijest), no i dodatno povezivanje s materijalnim (mišljenje kao jedenje). Konvencionalni izraz smještenosti biti u mislima kao odraz tipične konceptualizacije uma kao unutarnjeg prostora koji ispunjavaju (u kojem egzistiraju) ideje i koncepti koji upućuju na stvari iz vanjskog, fizičkog svijeta (usp. Lakoff i Johnson 1999: 266), zamjenjuje i konceptualizaciju svijesti kao spremnika te još dalje naglašeno unutarnji omeđeni prostor spremnika povezuje s nesvjesnim. Iz klasifikacije primjera za pojam svijest vidljivo je da nisu pronađeni primjeri u kojima se svijest konceptualizira kao spremnik, ${ }^{27}$ nego se kao spremnik konceptualiziraju misli i nesvijest, ${ }^{28}$ čime se naglašuje i autorski podcrtava analogija misli i nesvjesnog.

\subsection{Mravi}

Izrazi za mrave nisu denotativno izjednačeni s mislima i apstraktnim, no brojne su poveznice u konceptualnim područjima, posebno u značenjskim skupinama koje se odnose na pretvorbe, zapremanje prostora i na radnje (posebno na kretanje).

(1') objekt

(1'a) posjedovanje

Bez zlatijeh tih mrava jošte se po sve dni (3121)

(1'b) pomicanje

(sova iz svrake) ter žive sve mravi prohodom izvrže. (174)

... u što ću skupit te mravi. (190)

ke ne viem pobrati ni poniet odtole, (777)

Ako bih pobral sad od zlata te mravi, (3187)

A zlate sve mravi, neka t' je još znati, | ke laze po travi, hotil bih sabrati, (3095-3096)

A to jes, da zberu od zlata sve mravi, | pri ovomu jezeru ki laze po travi. (3195-3196)

A zlate te mravi, (...) ke misliš pobrati, (3165-3166)

pokupi te mravi i shrani s tobom sve (3113)

(mojemuča) od zlata gonjaše mravalja velik broj (2882)

Tiem čini, da parjaš te mravi zlaćene, (3181)

24

Grčevi u trbuhu, koje kod Piligrina uzrokuje svađanje misli, ujedno su i sastavnica »kuhinjskoga humora«, uobičajene motivike latinskoga pjesništva, pa primjerice: »... Fortunat prikazuje $u$ deset stihova, koji parodiraju epski stil, grčeve u trbuhu, prouzročene prekomjernim uživanjem bresaka.« (Curtius 1998: 468) U glavnini primjera koje donosi Curtius riječ je o kritici proždrljivosti.

25

Ta slika tučnjave misli nije bez parodijskih i komičnih elemenata koji se mogu naći i u Pokladu i Korizmi (usp. Marulić 1993).
26

Interpretirajući djela Lewisa Carrolla, Deleuze izdvaja alternativu jesti ili govoriti upravo kao alternativu unutra-vani. (usp. Deleuze 2015: 27)

27

U djelima starih pisaca uobičajeni su konvencionalni metaforični izrazi: biti $u$ ili van svijesti, u svojoj dobroj svijesti, v. ARj XVII: 260 i 262).

28

I pride pak sova, leteći u nesvies | od njekud iz lova, jaki no manen bies. (169-170), zanese klupko toj ne viem kud u nesvies (1881). 
(1'c) djelovanje

apstraktno

Liepe su na svieti od zlata te mravi | očima vidjeti človječjoj naravi, (3175-3176)

Mojemuča rekši toj, od zlatieh tih mravi (3183)

na pokon sve mravi životom da plati; (156)

(sova svraku) u gramfu uhvati da mravlje osveti. (172)

i ko se zlo pati rad mravalj od zlata; (3170)

i u vrieme u svako za-č rad tizieh mravalja (3173)

konkretno

gdje mravlje pozoba i niedne ne ostavi, (132)

toj li bi ostavio od mravi tuj liepos, (3189)

ja medvjed u zao čas pozobah sve mravi, (138)

(svraka) ter niednu ne odje od mravalj leteći. (168)

(vila) tiem mravljem ter krila tutako pristavi, (162)

skrovni su porazi, ne takni te mrave, (3101)

da javi ni speći pritužna svies svoja | te mravlje gojeći ne prija pokoja. (3179-3180)

Tvoj trbuh nadmeni za-č se će zaduti, | i mravi zlaćeni u muke svrnuti. (3215-3216)

Na pokon i prah taj stvori se mravljami (...). (115)

Mravi su u navedenim primjerima uglavnom u nemetaforičnim izrazima koji su sekundarno predmetom simbolizacije, no u pojedinim se značenjskim skupinama uspostavlja i analogijski odnos s mislima. Мојетис̌a upravlja kretanjem zlatnih mrava kao što sabire misli iz prosa. Mravi su objekt pretvorbi kao i objekt pokušaja skupljanja pri čemu do izražaja dolaze osobine rasutosti pojedinačnih mnoštava. Mravi su u ulozi teme predmet govora i objekt osjetila (vida) te uzrok (sve mravi životom da plati) ili motivacija (namjera) djelovanja (da mravlje osveti).

(1") agens

(1"'a) kretanje i zapremanje prostora

ter mravlje pridoše, kojiem se ne zna broj, (117)

Pak mravlje pridoše pod javor, gdi ja bjeh, (121)

Mojemuča nu meni o štapu dobata | pod borak zeleni, s mravljami od zlata; (2905-2906)

i u pored te mravi istakmila bješe, | da sliede drum pravi, kud sama hotješe. (2883-2884)

te mravlje gdje gledah lazeći vrh mene, (124)

pri ovomu jezeru ki laze po travi. (3196)

A zlate sve mravi, neka t' je još znati, | ke laze po travi, hotil bih sabrati, (3095-3096)

Nu stekši krila taj, to više leteći, (165)

Nu mravlje zgrizoše medvjedov trbuh taj | ter žive pridoše opeta na svit saj; (159-160)

gdje u mojoj utrobi koporu sve mravi | i trbuh moj grizu, da opeta na bil dan | sve žive izljezu iz moga kruga van. (142-144)

što u zemlji ne htjehu kopati sebi stan, (126)

običaj kako je od svoje naravi, | u vrieme da stoje pod zemljom sve mravi. (127-128)

u pustoj dubravi gdje su misli moje, | od zlata gdje mravi pod javorom stoje, (775-776)

te mravi zlaćene neka su u stogu | na jedno hranjene pri meni nebogu. (3097-3098)

(1'b) djelovanje

apstraktno

stekoše smrtni vaj, poginut ne mneći; (166)

konkretno

gdje mravlje zlaćene, ke me u san moriše, | u muhe lajnene do jedne se stvoriše, (3243-3244)

tutatko mrav svaka od zlata satvori; (176)

jadovno za dosti nu štiplju, nu prude, (3177)

za-č mravi te prišad jaše me štipati, (3203) 
i mravlje zlaćene svies moju skončaju; (3192)

sve meso do kosti ter moje grizjehu; (3206)

gdje u mojoj utrobi koporu sve mravi | $i$ trbuh moj grizu, da opeta na bil dan | sve žive izljezu iz moga kruga van (142-144)

$\mathrm{Nu}$ mravlje zgrizoše medvjedov trbuh taj| ter žive prodoše opeta na svit saj; (159-160)

ter vajmeh zgrizoše do zrna proso toj, (118)

ter meni zgrizoše do krpe šupalj mieh; (122)

Zgrizle su mravlje mieh, u kom ja do groba. (183)

Mravi se kreću prema van (iz spremnika), na otvoreno, u spremniku (koji je tijelo-trbuh i zemlja), laze (po tijelu i po zemlji-travi) te lete. Ponekad su u kretanjima vođeni (vodi ih mojemuča sa štapom), no češće se kreću personificirano i nekontrolirano. Mravi izvode i apstraktno djelovanje (mišljenje), no ne govore i ne izražavaju osjete, samo su predmet i objekt govora i osjetila te uzrok djelovanja.

Konkretno djelovanje odnosi se na vlastito tijelo (pretvorbe) te na djelovanje na drugo tijelo (štipanje i grizenje), na um (skončavanje svijesti) te na predmete (grizenje). Grizenje i jedenje trbuha drugoga tijela ima za cilj kretanje, izlazak iz spremnika, oslobađanje koje je i izvanjštenje iz osobe koja je subjekt (iz moga kruga van) kao i dezintegracija drugoga tijela (spremnika). U tim primjerima posebno do izražaja dolazi nemogućnost uspostave kontrole nad personificiranim rasutim mravima, te ujedno i analogija mrava s otjelovljenim mislima. Bježačke pretvorbe mrava u druga obličja forme su reteritorijalizacije i kreacije (usp. Deleuze i Guattari 2013: 66). Kretanje mrava, koje uključuje njihovu pretvorbu, osim što ima liniju bijega i stalnog obnavljanja (čime je i ciklično), sastavnicom je interakcije (koja je na konceptualnoj razini više pretapanje negoli hijerarhija) materijalnoga svijeta, tijela i apstraktnih entiteta, koju interakciju kognitivisti prikazuju u hijerarhiji objedinjenoj kulturalnim modelom velikoga lanca. ${ }^{29}$

Simbolika mrava, osim na organizaciju »života u zajednici« (usp. Chevalier i Gheerbrant 1994: 417) upućuje na tjelesno i materijalno. ${ }^{30}$ Metaforično stanište mrava jest trbuh (s prijenosom značenja mravinjak-zemlja-trbuh), a generiranje pretvorbi njihovo je tipično djelovanje. ${ }^{31}$

29

Razmatrajući Merwinove Asian Figures, organizirane kao prijevodi izreka, koje su i upute za razumijevanje ljudi i svijeta, Lakoff i Turner osvrću se na stihove:

Ants on a milestone whichever way they walk they go around with it

kao na hijerarhijsko metaforično preslikavanje, " pitanja višega reda odgovaraju opisima nižega reda: ljudsko mjesto u svijetu izrazom mrava na putokazu« (Lakoff i Turner 1989: 161, prijevod G. Č.). Kognitivni model velikoga lanca bića i osobine smještaju na vertikalnu skalu: »Kad govorimo o čovjekovim 'višim' obilježjima, mislimo na njegov estetski i moralni osjećaj te sposobnost razuma, ne na njegove tjelesne značajke, animalne žudnje ili sirove strasti. Govorimo o višim i nižim oblicima života. Veliki Lanac ljestvica je oblika bića - ljudi, životinje, biljke, neživi predmeti - i slijedom toga ljestvica osobina koje obilježuju oblike bića - razum, instink- tivno ponašanje, biološke funkcije, fizička svojstva itd.« (Lakoff i Turner 1989: 167, prijevod G. C.)

30

Toj je funkciji donekle podudarno razmatranje simbolike zlatnih mrava u značenju »pohlepe, novca ili kapitala« (usp. Rafolt 2009: 175), odnosno »zlata, bogatstva« (usp. Grmača 2010: 413).

31

U određenim kulturama mravinjak je i zemljin spolni organ te mjesto koje generira plodnost i pretvorbe ljudi u životinje. Zemlja mravinjaka »kojom se u vezi sa čovjekovim trbuhom i probavnim funkcijama obredno služe neka inicijacijska udruženja, simbolizira energiju što kruži zemljinom utrobom, a očituje se $u$ obliku izvora. U Maroku su bolesnicima obuzetim mrtvilom davali gutati mrave« (Chevalier i Gheerbrant 1994: 417). 
Povezivanje uma s mravima i govorom usko je povezano i s konceptualizacijom proizvodnje simboličnih uzoraka. ${ }^{32}$

Misli i mrave u djelu povezuje rasutost, mnogostrukost, kretanje, bijeg te privremena prisilna smještenost (pokušaj zarobljavanja) u zatvorenom spremniku (mijehu ili trbuhu). ${ }^{33}$ Propada svaki pokušaj skupljanja rasutih mnogostrukosti, kao pokušaj uspostave kontrole (nad mislima, mravima i značenjima) pa slijedom toga i mišljenje kao jedenje i jedenje kao bijeg s područja dualizma i hijerarhije velikoga lanca prelaze na polje kontinuiranog produciranja linija pretopljenog svijeta. ${ }^{34} »$ Viši $\ll \mathrm{i} » n i z ̌ i \ll$ dijelovi lanca: razum, instinktivno ponašanje i biološke funkcije, posredstvom materijalizacije apstraktnog, prepleteni su i izjednačeni pa je »kaotični« svijet Pelegrina svijet eksperimentiranja i razobličenja, udaljen od shematiziranoga dualizma, a približen materijalnoj stvarnosti. ${ }^{35}$

\section{Zaključak}

Proučavani primjeri pokazuju tendenciju propitivanja ustaljenih i tipičnih odnosa unutra-van: uma smještena u tijelu i nesvjesnog sakrivenog u umu. Upravo se na izokretanju ustaljene opozicije unutra-van temelji i »obratnost« prikazanoga svijeta. Posredstvom otjelovljenosti i materijalizacije uma konceptualizira se izvanjštenje, koje je istodobno eksteritorijalizacija i dezintegracija tijela. Svijest odlazi putovati vanjskim prostorom, svijetom, misli nisu smještene u glavi nego u mijehu koji se nosi u ruci, zatim u otvorenom prostoru, u kojem doživljavaju različite pretvorbe, te u drugim tijelima i u trbuhu onoga kome izvorno pripadaju.

Vetranovićevo se peregrinacijsko putovanje, slijedom proučavanih primjera, pokazuje putom kroz vlastiti um. Pri tome se razine svijesti, koje su i prostori uma, materijaliziraju kao tri tijela: nesvjesno materijalno (mravi, proso), nesvjesno apstraktno i materijalno (misli kao spremnik, predmet i osoba) te svjesno apstraktno i materijalno (svijest kao tijelo). Materijalizacija unutarnjeg prostora posebno je iskazana izrazima metafore MIŠLJENJE JE JEDENJE, dok je izvanjštenje iskazano izrazima metafora MIŠLJENJE JE KRETANJE i MIŠLJENJE JE GOVORENJE. Na razdjelnici unutra-van odvija se i dvojstvo subjekta i sebe, a ta je razdjelnica povezana i s konceptom rasutosti (bijeg iz i skupljanje unutra, misli i mravi).

Razmatranje konceptualnih područja izdvojenih pojmova usmjerava potragu za kauzalnošću zbivanja i motivacijom tijeka događaja u djelu te na prikazivanje izmjenjivanja različitih razina sna $\mathrm{i}$ (pod)svijesti. U tome je Vetranovićev pretopljen i kaotičan svijet mnogo realističnija slika vizije nesvjesnoga od slike segmentiranoga, hijerarhiziranoga i vertikalnoga svijeta srednjovjekovnih vizija ${ }^{36}$ i alegoriziranih hodočasničkih putovanja; a ujedno i izrazito moderna. ${ }^{37}$

U tom su kontekstu intrigantne konstrukcije (nepronađenog ili nepostojećeg) završetka djela funkcionalnije kao čitateljev nastavak mentalnog putovanja, a znatno manje kao potraga za etičkim i teološkim poučkom. Putovanje koje je i eksperimentiranje dovodi putnika u stalne nevolje, no nevolje osim kazne mogu biti i opravdanje te ne moraju nužno voditi spoznaji višeg apsoluta smještenoga iznad uma samoga. 


\section{Literatura}

ARj: Rječnik hrvatskoga ili srpskoga jezika (1880-1976) I-XXIII, JAZU, Zagreb.

Belaj, Branimir; Tanacković Faletar, Goran (2014): Kognitivna gramatika hrvatskoga jezika. Knjiga prva: Imenska sintagma i sintaksa padeža, Disput, Zagreb.

Belaj, Branimir; Tanacković Faletar, Goran (2017): Kognitivna gramatika hrvatskoga jezika. Knjiga druga: Sintaksa jednostavne rečenice, Disput, Zagreb.

Chevalier, Jean; Gheerbrant, Alain (1994): Rječnik simbola: mitovi, sni, običaji, geste, oblici, likovi, boje, brojevi, preveli Ana Buljan i dr., Nakladni zavod Matice hrvatske, Mladost, Zagreb.

Curtius, Ernst Robert (1998): Europska književnost $i$ latinsko srednjovjekovlje, preveo Stjepan Markuš, Naprijed, Zagreb.

Deleuze, Gilles; Guattari, Félix (2013): Kapitalizam i shizofrenija 2: Tisuću platoa, preveo Marko Gregorić, Sandorf \& Mizantrop, Zagreb.

Deleuze, Gilles (2015): Logika smisla, preveo Marko Gregorić, Sandorf \& Mizantrop, Zagreb.

Fališevac, Dunja (1988): »Elementi grotesknog i fantastičnog u Vetranovićevu 'Pelegrinu' «, Dani hvarskog kazališta 14 (1988) 1, str. 215-228.

Fauconnier, Gilles; Turner, Mark (1998): »Conceptual Integration Networks «, Cognitive Science 22 (1998) 2, str. 133-187. doi: https://doi.org/10.1207/s15516709 $\operatorname{cog} 22021$.

32

Misli su pri tome predstavljene kao manipulacije formalnim simbolima, a um kao računalni program. Kognitivisti zbog naglašavanja kulturnih okvira otklanjaju svođenje uma na formule, no znakovito je da kreiranju programa umjetne inteligencije, za koje je ključno razumijevanje i apstrahiranje mentalnih uzoraka, pridonose i eksperimentalna istraživanja obrazaca pojedinačnog i skupnog ponašanja mrava, kao primjer antropomorfizma u ponašanju životinja (usp. Kitabayashi i dr. 2001).

33

Deleuze i Guattari predstavljaju rizom i kao životinje u čoporu i kao brlog u funkcijama "staništa, zalihe, pomaka, bijega i raskida« (2013: 13). Opisujući načelo obeznačujućeg raskida uspostavljaju analogiju između rizoma i mrava (2013: 16) te mrave izdvajaju i kao sastavnicu halucinantnih slika (2013: $31)$.

34

Stavljajući djelo u okvire renesansne filozofije Rafolt posebno izdvaja postavke filozofske antropologije za koje se također može reći da su u znatnoj mjeri utemeljene na metafori velikoga lanca: »U složenijim inačicama, primjerice i kod Marsilija Ficina, razumska duša pristupa materiji, pa nakon toga oblikuje četiri entiteta: oblik materije, oblik pomiješanoga tijela, oblik biljke i oblik životinje« (2009: 161). Ujedno ističe kako je moguće da Vetranovićevo djelo posreduje kritiku na srednjovjekovni antihumanizam, (pseudo)animalizam koji je bio u funkciji osporavanja kršćanske ideologije (Rafolt 2009: 188).
35

Umjesto potrage za poetskim i stvarnim regulativima svijeta Vetranovićeva spjeva valja se otisnuti u zakutke materijalizirana uma i u forme »rastepnuća« tijela i sebe, čime se prelazi u potragu za deleuzeovskim tijelom bez organa (usp. Deleuze i Guattari 2013: 171) te piscem-vračem koji postaje kako kukcem, štakorom ili vukom (usp. Deleuze i Guattari 2013: 268), tako i pticom ili medvjedom.

36

Takvo je primjerice Dundulovo svjedočanstvo o iskustvima trodnevne nesvijesti (usp. Hrv. srednj. proza II., 2013).

37

Akauzalnost u odvijanju događaja i pojavljivanju likova obilježuje putovanje različitim razinama sna u Nolanovu filmu Inception (2010), temeljenu i na Deleuzeovim razmatranjima prostora i vremena. Zamagljivanje granice između sna $\mathrm{i}$ stvarnosti te između stvarnog i fikcijskog s ciljem predočavanja i materijaliziranja unutarnjeg prostora uma, topos je književnih djela i filmova (usp. Žižek 1999). U toj se funkciji i Čirčina spilja pokazuje ekvivalentom Stalkerovoj sobi, kao mjesto u kojem se ispunjavaju želje i kao odredište peregrinacijskoga puta $u$ materijalizaciju nesvjesnog. »Narativno kašnjenje« koje Rafolt izdvaja kao posljedicu subjektivnog, unutarnjeg motrišta i kao pokazatelj fantastičnog čudesnog (»u kojemu se priče predstavljaju fantastičnim, ali završavaju prihvaćanjem natprirodnog kao normalnog «, 2009: 193) u tom se kontekstu svojom opetovanošću također pokazuje jednim od sredstava zamagljivanja granica realnog i čudesnog. 
Grmača, Dolores (2009): »Držić i Vetranović: suhi javor i Dugi Nos«, Dani hvarskog kazališta 35 (2009) 1, str. 152-173.

Grmača, Dolores (2010): Alegorija putovanja u hrvatskoj renesansnoj književnosti, doktorska disertacija, Filozofski fakultet, Zagreb.

»Hrvatska srednjovjekovna proza II.« (2013): U: Dürrigl, Marija-Ana (ur.), Stoljeća hrvatske književnosti, Matica hrvatska, Zagreb.

Kitabayashi, Nobuhide; Kusunoki, Yoshiyuki; Gunji, Yukio-Pegio (2001): »The Logical Jump in Shell Changing in Hermit Crab and Tool Experiment in the Ants«, u: Kitamura, Tadashi (ur.), What Should be Computed to Understand and Model Brain Function?, World Scientific, Singapure, New Jersey, London, Hong Kong, str. 183-206.

Kravar, Zoran (1980/1981): »Emblematika Vetranovićeva 'Pelegrina'«, Filologija 10 (1980/1981), str. 315-324.

Lakoff, George; Johnson, Mark (1980): Metaphor We Live By, University of Chicago Press, Chicago.

Lakoff, George (1987): Women, Fire, and Dangerous Things: What Categories Reveal about the Mind, University of Chicago Press, Chicago.

Lakoff, George; Turner, Mark (1989): More than Cool Reason: A Field Guide to Poetic Metaphor, The University of Chicago Press, Chicago, London.

Lakoff, George; Johnson, Mark (1999): Philosophy in the Flesh, Basic Books, New York.

Lupić, Ivan (2014): »Pelegrinov otpor«, u: Pišković, Tatjana; Pišković, Tvrtko (ur.), Otpor: subverzivne prakse u hrvatskome jeziku, književnosti i kulturi, Zagrebačka slavistička škola, Zagreb, str. 35-79.

Marulić, Marko (1993): Pisni razlike, Književni krug, Split.

Pavličić, Pavao (2007): Epika granice, Matica hrvatska, Zagreb.

Rafolt, Leo (2009): Drugo lice drugosti. Književnoantropološke studije, Disput, Zagreb.

Stanojević, Mateusz-Milan (2013): Konceptualna metafora, Srednja Europa, Zagreb.

Turner, Mark (1996): The Literary Mind, Oxford University Press, New York, Oxford.

Vetranović, Mavro (1872): »Pjesme Mavra Vetranovića Čavčića«, u: Jagić, Vatroslav; Kaznačić, Ivan August; Daničić, Đuro (ur.), Stari pisci hrvatski, JAZU, Zagreb, IV, II.

Žic Fuchs, Milena (1992/1993): »Konvencionalne i pjesničke metafore«, Filologija 2021, str. 585-593.

Žižek, Slavoj (1999) »The Thing From Inner Space«. Dostupno na: http://www.lacan.com/ zizekthing.htm (pristupljeno 11. 2. 2017.).

\title{
Gordana Čupković
}

\section{The Representations of Mind in Vetranović's Pelegrin}

\begin{abstract}
This paper deals with semantics of Pelegrin, a narrative poem written in the $16^{\text {th }}$ century by Mavro Vetranović. The author categorises and interprets, from a cognitive point of view, literal and metaphorical expressions that are focusing on the mind, primarily the expressions of the concepts of consciousness, thoughts, and ants. The conceptual content, the embodiment and the cultural frames of the studied examples are considered. By analysing the conceptual content and emphasizing the universal grounding of metaphorical expressions, the focus from the interliterary influences is shifted to the images of unconsciousness as essential properties of the meanings produced in the poem.
\end{abstract}

\section{Key words}

Mavro Vetranović, cognitive semantics, conceptual metaphor, embodiment, mind, consciousness, unconscious 